\title{
Fragile Identities, Capable Selves
}

\author{
Roger W. H. Savage \\ University of California at Los Angeles
}

\begin{abstract}
The spotlight that Martha Nussbaum turns on the plight of women in developing nations brings the disproportion between human capabilities and the opportunities to exercise them sharply into focus. Social prejudices, economic discrimination, and deep-seated traditions and attitudes all harbor the seeds of systemic injustices within governing policies and institutions. The refusal on the part of a dominant class to recognize the rights and claims of subaltern individuals and groups has both symbolic and material consequences. The power that one group exercises over another brings the refusal to recognize the rights and claims of others to the fore. Thanks to the moral priority that Paul Ricoeur accords to the victim against such refusals, I tie the fragility of identity to the idea of justice's federating force. This federating force, I therefore argue, accompanies the struggle for recognition among capable human beings.
\end{abstract}

Keywords:

\section{Résumé:}

La lumière que Martha Nussbaum jette sur le sort des femmes dans les pays en développement met en évidence la disproportion entre les capacités humaines et les possibilités de les exercer pleinement dans le foyer. Les préjugés sociaux, la discrimination économique, les traditions et les attitudes profondes renferment toutes les racines d'injustices systémiques que l'on trouve dans les politiques gouvernementales et les institutions. Le refus de la part d'une classe dominante de reconnaître les droits et les revendications des individus et des groupes minoritaires a des conséquences à la fois symboliques et matérielles. La puissance qu'un groupe exerce sur un autre charrie le refus de reconnaître les droits et les revendications des autres. Grâce à la priorité morale que Paul Ricoeur accorde à la victime contre ce refus de reconnaissance, j'attache à l'idée de la force fédératrice de la justice la fragilité de l'identité. Je soutiens donc que cette force fédératrice accompagne la lutte pour la reconnaissance parmi les êtres humains capables.

Mots-clés:

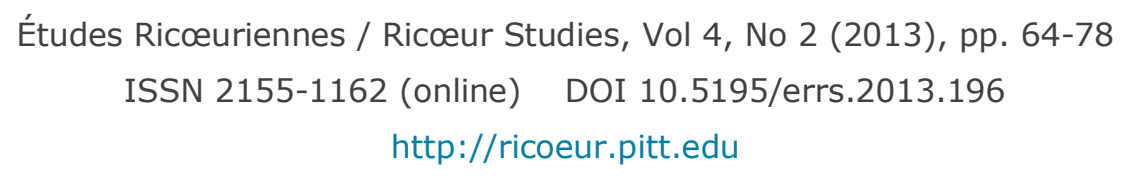

\section{(cc) BY-NC-ND}

This work is licensed under a Creative Commons Attribution-Noncommercial-No Derivative Works 3.0 United States License.

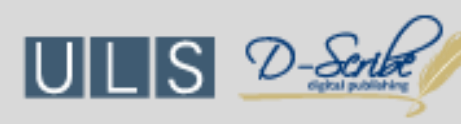

This journal is published by the University Library System of the University of Pittsburgh as part of its D-Scribe Digital Publishing Program, and is cosponsored by the University of Pittsburgh Press. 


\title{
Fragile Identities, Capable Selves
}

\author{
Roger W.H. Savage \\ University of California at Los Angeles
}

The vulnerability of already marginalized individuals and groups figures prominently in the struggle for equal rights and opportunities for all. Circumstances and conditions that disproportionately affect those who have been denied privileges and advantages enjoyed by others are too often symptoms of systemic injustices within a ruling socio-political order. The violence that these injustices inflict on vulnerable populations is indicative of the place of suffering in human affairs. The demand for justice thus joins the demand on the part of different communities and their members to be accorded the right and the opportunity to exercise their capacities and powers.

Attributing these systemic injustices to the decrease of one's power to act highlights the harm wrought when individuals and groups are rendered less capable, or incapable, of exercising their abilities. Individuals and groups who are barred from participating in public will formation or who suffer from a lack of opportunity and access to education, employment, health services, and other social goods, lack power to exercise the capacities that inhere within the human condition. The refusal to recognize others as capable human beings adversely affects the sense of others' self-worth to the detriment of all. Any account of suffering, Paul Ricoeur adds, must also take into account the more deeply concealed forms of suffering that afflict human beings, including the "incapacity to tell a story, the refusal to recount, [and] the insistence of the untellable." 1 Traumas, humiliations, and psychic wounds consequently figure among the instances of violence that mark the disproportion between the power to act and the experience of undergoing and enduring the effects of the actions of others.

By tying the experience of suffering to the harm done to individuals and groups whose ability to exercise their capacities and powers has been diminished or thwarted, I intend to explore the connection between the struggle for recognition and the idea of justice's federating force. This exploration into the moral-ethical demand that animates this struggle does not exhaust the question regarding the problem of violence and suffering. My aim is therefore more modest: to investigate how the moral priority that belongs to the victim relates to the demand for a just share in the opportunities to exercise the abilities and powers that are the prerogative of capable human beings. In turn, this investigation opens the way to a broader consideration of the place that the demand to the right to be different has with respect to the idea of humanity as a collective singular.

\section{Vulnerable Human Beings}

The spotlight Martha Nussbaum turns on the plight of women in developing nations brings the disproportion between human capacities and the opportunities to exercise them sharply into focus. The lives of two women in India whose stories Nussbaum recounts bear witness to the adverse effects of their social and political disadvantages. Vasanti's life, Nussbaum emphasizes, has largely been scripted by the men on whom she depends. After spending the 
household money, her husband - a gambler and alcoholic - accepted the cash incentive to have a vasectomy provided by the local government before abandoning Vasanti, leaving her childless and without support. Vasanti was also a victim of domestic violence, losing, in Nussbaum's words, "her emotional equanimity to fear, and being cut off from meaningful forms of affiliation, familial, friendly, and civic." 2 For these reasons, Nussbaum explains, Vasanti "did not really have the conception of herself as a free and dignified being whose worth is equal to that of others." 3 Vasanti is now a member of the Self-Employed Women's Association (SEWA) in Ahmedabad, Gujarat, the "textile mill city where Mahatma Gandhi organized labor in accordance with his principles of nonviolent resistance." 4

Jayamma, in contrast, had no male relatives on which to depend. She worked as a laborer at a brick kiln for approximately forty-five years, where she carried 500 to 700 bricks a day balanced on her head. Unlike many men in the brick industry, she was never promoted to the better paying, more skilled, and less arduous jobs. Now retired in her mid-sixties, she has few resources on which to fall back. Her pride in keeping her family together and improving its social standing, Nussbaum explains, "is uneasily combined with the conviction that she cannot expect from life the things other more privileged people will easily get." ${ }^{5}$

Vasanti and Jayamma's life experiences are a testament to the symbolic and material consequences of the refusal on the part of dominant classes to recognize the capabilities, rights, and claims of subaltern individuals and groups. Moreover, the lack of equality in social and political circumstances disproportionately affects women's abilities to exercise their powers and capacities. Conditions of extreme poverty exacerbate existing gender inequalities, resulting all too frequently in an acute failure to promote the rights and dignity of all human beings. Social prejudices, economic discrimination, and deep-seated traditional practices and attitudes harbor the seeds of systemic injustices within governing policies and institutions. Blindness to the suffering wrought by the social and economic advantages one group, class, or nation enjoys at the expense of another fuels resentments fed by humiliations, traumas, and symbolic wounds. This blindness and these resentments consequently inflame hostilities inscribed within systemic orderings of dissymmetrical relations of power.

That the refusal to recognize the rights and abilities of others disproportionately affects the lives of already disadvantaged individuals and groups underscores this refusal's strategic value as an instrument of violence. In Nussbaum's view, both Vasanti and Jayamma "lacked an understanding of themselves as citizens who have rights that are being violated." 6 Hence neither was free to think and choose for herself. The violation of their rights as autonomous individuals thus only deepened the systemic corruption of relations among human beings. The violation of these rights is indicative of the lack - and even the refusal-of recognition. In turn, this refusal underscores the fragility of an identity confronted by the threat posed by others, the heritage of a founding violence, and the vagaries of time.

\section{The Fragility of Identity}

By relating the fragility of identity to the demand for recognition, I want to highlight how the idea of justice's federating force sets the vulnerability of capable human beings into relief. This federating force, Ricoeur suggests, arises in response to the violence of history and the abuses of memory that prolong this history of violence's insidious effects. Justice, he reminds us,

is the one virtue par excellence that, "by its very constitution, is turned toward others."7 Hence 
justice wrests the "component of otherness inherent in all the virtues ... from the closed-circuit of the self within itself." 8 By tying the idea of justice to the duty of memory, Ricoeur underscores the moral priority that belongs to history's victims. "The victim that is at issue is [therefore] the other victim, other than ourselves." ${ }^{\prime 9}$ Consequently, the duty of memory is not limited to preserving the past's material traces; it also "maintains the feeling of being obligated"10 toward those who, having gone before us, are a part of our own heritages.

The moral priority belonging to the victims of ethnic and religious conflicts, revolutions, colonialist exploits, and the rise of modern nation-states highlights how the harm inflicted on vulnerable groups feeds on the fragility of our identities. This fragility, Ricoeur explains, stems from identity's purely presumptive character. In response to the question "Who am I?" or "Who are we?" we claim to provide the recipe of our identity in terms of what we are. The fragility of these responses consequently constructs a precarious bulwark against the risks and threats to who we proclaim ourselves to be.

The first cause of the fragility of identity springs from our identity's status with respect to its permanence in time. For Ricoeur, the equivocal notion of being the same over time points to a split in the concept of identity. By reserving the term idem identity for sameness, Ricoeur relates ipseity or ipse identity to the sense of constancy appropriate to an agent who is capable of keeping her word.11 The difficulty raised by the problem of our identity's temporal component justifies the recourse to memory "in conjunction with the evaluation of the present and the projection of the future."12 Conversely, the retreat from ipse identity to idem identity opens the gateway to our identities' ideological deformation. The temptation of vesting this identity with the prestige of its immutability bears out the threat posed by the vagaries of time. We are all aware that the ravages provoked when "ideologists try to ... remove ... the bite of time"13 disproportionately affect those who suffer under another's rule. Under the guise of some identity's celebrated immutability, essentializing representations of denigrated and execrated groups serve as justification for the victors' rule.

The impulse to exclude others bears out a second cause of our identity's fragility. Like us, others have their ways of "leading their lives, of understanding themselves, [and] of inscribing their own identity in the web of living together."14 The ideals embodied in these ways of living pose a threat to the extent that they conflict with cherished traditions, practices, and ambitions. Different ways of living thus constitute a field of contested values that are the sites of differences stemming from competing and conflicting claims.

The third cause of the fragility of identity - the "heritage of founding violence"15highlights the paradox of a state of right. Such a state rests on the belief in the legitimacy of its claim to rule. The supplement that ideology adds to this belief underscores the precarious nature of the institution of a system of rights that recognizes and guarantees equal protections and opportunities for all. Founding events are essentially acts of violence "legitimated after the fact by a precarious state of right." 16 The crisis of delegitimation that Ricoeur argues is symptomatic of the loss of authority in the modern world is indicative of the degree to which all claims regarding the right to rule have become suspect. In response to blows of rejection and humiliation, the claim to the right to be different thus acquires a militancy that fuels the distinctive pathos of an identity couched in the modern vocabulary of authenticity.

Tying the claim to the right to be different to the loss of authority has the advantage of highlighting how different threats to an individual or group's identity inflame tensions and 
conflicts between them. To the extent that ideals embodied in one way of living clash with cherished traditions and practices of another, aspirations regarding the identity and autonomy of each give rise to competing claims. Ricoeur reminds us that the symbols ruling over identity derive as much from future expectations as from the cultural deposit of the past. The identity of a community, he therefore says, is also a prospective identity. ${ }^{17}$ Religious, ethnic, cultural, and gender differences thus become sites of contested values that are inseparable from demands for recognition. By itself, each way of living holds out the prospect-received and chosen-of the "good" life. Together, the plurality of these ways of living-and the goods to which each lays claim - constitutes a field of contested differences that attests to the demand on the part of each to the right to live in accordance with one's own decisions and convictions.

Stuart Hall underscores the role that different cultural representations play with respect to a group's view of its history and aspirations. By focusing on post-colonial representations of the black subject, he puts the notion of an authentic, authoritative identity radically into question. For him, the idea of a shared sense of self rooted in a common history and ancestry plays a vital political role in post-colonial struggles. By setting the "imaginary fullness or plenitude"18 of connections with an African past against the West's visual and cinematic representations, the photographic work of a generation of Rastafarian and Jamaican artists, for example, provides resources for resisting the West's hegemonic rubric. Every regime of representation, Hall maintains, is a "regime of power formed, as Foucault reminds us, of the fatal couplet, 'power/knowledge'."19 By internalizing the images promulgated by colonialist authorities, subjugated individuals and groups learned to see and experience themselves as the objects of imperialist regimens of knowledge and power.

The role that memory plays in struggles against the legacy of colonialist regimes highlights tension between identity's prospective dimension and its ideological deformation and even cooptation. Ideology, Ricoeur reminds us, provides a "symbolic response to the causes affecting the fragility of this identity" 20 by constituting the network through which we articulate our experiences and understandings of the world, our feelings, and our positions in society. All representations are accordingly "symbolic mediations contributing to the instituting of the social bond." 21 By symbolizing identities that "confer a particular configuration on these social bonds as they are formed," 22 representations that provide a group with an image of itself constitute real stakes in its quest to realize its dreams and aspirations.

Memory's mobilization in the service of this quest not only opens the way to renewing and revitalizing past heritages, but it also unleashes the abuses that arm social protagonists with symbolic weapons for denigrating and denying the capabilities of other human beings. ${ }^{23}$ Memory, Ricoeur points out, "can be ideologized through the resources of the variations offered by the work of narrative configuration." 24 This narrative configuration not only shapes the contours of the action but also contributes to modeling the identity of the narrative's different protagonists. By giving a narrative texture to the drama of human affairs, the tragic muthos relates the experience of suffering to the constraints that limit and condition our power to act. The tragic muthos, Ricoeur emphasizes, thus "serves as a counterpoint to ethics." 25 Where the recounting of events deploys a selective strategy of remembering as much as forgetting in the interest of authorizing one history at the expense of another, the identities of the victims are therefore always in danger of falling prey to the "official" histories with which the victors arm themselves.

The harm inflicted by means of denigrating images thus feeds on the fragility of identity. The absence of recognition or misrecognition that Charles Taylor suggests in part shapes-or 
better, misshapes - an individual or group's identity has proven to be a formidable weapon in the hands of imperialist regimes. ${ }^{26}$ Simianizing representations of the Irish peasantry in the late Victorian and early modern era, for example, surreptitiously legitimated British colonialist rule. ${ }^{27}$ Similar misrepresentations in the form of ethnic slurs, racial caricatures, and other essentializing attacks on the lifestyles and character of those who are different fuel the inclination toward intolerance and violence through vesting this refusal with its self-justificatory air. To the extent that members of execrated groups internalize these willful mischaracterizations, the symbolism that arms these slurs and attacks takes hold in self-deprecating images that undermine the member's confidence in their capacities and powers. ${ }^{28}$

Ricoeur emphasizes that the "seriousness of the lack of recognition of which members of these groups feel themselves to be the victims comes from the internalizing of this image in the form of self-deprecation." 29 The loss of confidence in one's own capabilities compounds the fragility of feelings of self-worth for those who are especially vulnerable to the precarious conditions of their social, cultural, and political situations.

\section{Violence and Passivity}

This loss of confidence evinces one of the most insidious forms of violence mobilized in the interest of maintaining different individuals and groups' prestige and power. In his 1992 Nobel address, Gary Becker "observed that women and minorities frequently underinvest in their own human capital" 30 because they have been brought up to believe that they are incapable of achieving a level of competence that other people can. Through internalizing "their secondclass status in ways that cause them to make choices that perpetuate that second-class status," 31 disadvantaged groups-including for Becker "blacks, women, religious groups, [and] immigrants" 32 - make the reasons for this underinvestment in education, training, and skills their own.

Attacks in the form of the belief in one's own lack of abilities are therefore not only symbolic. The material effects of the violence that accompanies the refusal on the part of a dominant group to recognize the capacities and rights of other autonomous human beings also exacerbates the harm directed against disadvantaged individuals and groups' self-esteem. Ann Stoler rightly condemns the ruination of cultural heritages and practices, traditional institutions, languages, religious beliefs, and rites. For her, the destruction of indigenous cultural landscapes is a "corrosive process that weighs on the future and shapes the present." 33 The ruins of empires are accordingly sites of "implacable resentment, disregard, and abandonment." 34 Deprived of the belief in their own capacities and powers, those who wander among these ruins are at risk of becoming trapped in the cycle of resentment and violence.

The role that memory's mobilization plays vis-à-vis the injustices that place their stamp on the inabilities or lesser abilities of different social protagonists underscores how the suffering inflicted on some to the advantage of others gives the struggle for recognition its moral and political force. This struggle sets itself against the refusal that I said earlier adversely affects the lives of already vulnerable individuals such as Vasanti and Jayamma through denying individuals advantages and opportunities enjoyed by others, and by undermining their confidence in their abilities and powers. If as Ricoeur argues the "authority of the symbolic order is both the ... site of the strongest connection between the self and the norm and the very principle of its [that is, the self's] fragility," ${ }^{\prime 35}$ the other's proscription as incapable of inscribing 
her or his action in such a symbolic order effectively excludes her or him from participating in a system where the distribution of social goods and public will formation contribute to enhancing individual members' self-respect and social esteem.

The force of this exclusion from the symbolic and material order in which others have a share once again evinces the kind of violence that human beings inflict on one another. The power that members of one group exercise over those of another, and the systemic social injustices that ensue when asymmetrical relations of power become inscribed in governing institutions, privilege some by disadvantaging others. The violence that turns capable agents into the patients of these systemic injustices consequently underscores the degree to which the system feeds on the element of passivity forced upon those for whom there seems to be no way out. ${ }^{36}$

By relating the power that one group exercises over another to the refusal of recognition, I mean to emphasize how this refusal accompanies the different instances of symbolic and material violence that corrupt relations among us. Ricoeur cautions: "most of the evil that comes into the world comes from violence among human beings." 37 The dissymmetry that he identifies as inherent to human interactions takes hold when one human being treats another as the patient of her or his action. The reign of suffering commences with the "decrease of the power of acting, ... [which is] experienced as a decrease of the effort" 38 to exist. Most of this suffering, Ricoeur adds, is inflicted on some by their fellow human beings. The reach of this suffering extends far beyond that of physical pain. Caught between one's disesteem of oneself and one's hatred for others, one's own sense of self-worth falls prey to the closed circuit of violence and despair.

The suffering inflicted through violence, however, does not exhaust the various registers on which experiences of passivity attest to the other's alterity. On the contrary, the violence some undergo at the hands of others is only the pathological expression of a more fundamental experience. Accordingly, Ricoeur identifies three modalities of passivity that correspond to different centers of otherness. The first modality is that of the "passivity represented by the experience of one's own body." 39 Here, the "certainty of the acting self and its contrary which is also its complement, corporal passivity," 40 gives rise to the dialectic between praxis and pathos. To say with Ricoeur, "I, as this man," highlights the "foremost otherness of the flesh with respect to all initiative." 41 For an ontology of the flesh, the dissociation of the notion of existence from that of substance frees the lived body from objectifying representations, so that one's own body becomes the organ and support of the initiatives that we take.

The second modality-the alterity of others-reveals the ethical, moral, and political dimensions of the self's relation to another, and to others. This second modality underscores the vulnerability to which we are exposed through our relations with others. Here, the exchange between the ascription of action to an agent and the agent's self-designation as the action's author reveals the reflexive bond between the two. The way that my actions affect another - that is, the "affection of the self by the other"42-places our action under the rule of justice. Ricoeur consequently holds that "[i]nasmuch as one is affected by the power over one exerted by the other, the agent is invested with the responsibility of an action that is placed from the very outset under the rule of reciprocity, which the rule of justice will transform into a rule of equality." 43 This rule is the riposte to the violence inflicted on vulnerable human beings. Accordingly, the federating force of justice acquires its practical handholds through advancing the recognition of every person's rights and capabilities. 
The third modality of passivity's center of otherness is conscience. In response to the injunction accompanying the assignment of responsibility, conscience bears witness to the demand coming from the other. As the voice of the Other, conscience bears witness to the obligation that places me in the other's debt. For Ricoeur, "[l]istening to the voice of conscience would signify being-enjoined by the Other." 44 Being-enjoined thus constitutes the "moment of otherness proper to the phenomenon of conscience." 45

The fragility attributable to the various threats to identity that time, the confrontation with others, and the history of a founding violence pose reveals the ways in which the features of these different registers bear on the capacities inscribed within the human condition. On the first register-that of one's own body - the passivity evinced by endured suffering attests to the will and desire to exist. As for the second register, the otherness inherent in intersubjective relations underscores the dissymmetry between an agent and a patient of action. According to Ricoeur, the passage from ethics to morality lies at this "intersection of the asymmetrical relation between doing and undergoing ... [, that is, between] the good you want to be done to you, [and] the evil you would hate to be done to you." 46 For him, the "affection of the ipse by the other than self" 47 justifies imposing the Golden Rule's commandment at this point of intersection between praxis and pathos. The third register crowns all three: to the call of conscience-the passivity of beingenjoined.

By reserving the term "otherness" for speculative discourse, Ricoeur highlights how, on the order of acting and suffering, "passivity becomes the attestation of otherness." 48 Experiences that attest to the alterity of the other ultimately prevent the self from occupying the place of ultimate foundation. This, Ricoeur stresses, is the main virtue of the dialectic at the heart of the hermeneutics of the self. Philosophical hermeneutics therefore belongs to the hermeneutical age of reason inasmuch as it protects itself against the hubris of setting itself up as the "heir to the philosophies of the cogito and as continuing their self-foundational claim." 49 Set between the cogito's philosophical elevation and its debasement, this hermeneutics joins a meditation on the fragility of the self to an inquiry into the figures of vulnerability illuminated by a philosophical anthropology of the capable human being.

\section{Capabilities}

By setting the fragility of identity against the backdrop of this philosophical anthropology, I want to draw out the connection between the causes of our identities' fragility and our vulnerabilities. The fragility of our identities, I suggested above, is bound up with the refusal on the part of others to recognize us as autonomous individuals with an equal claim to rights enjoyed by others as well as to our own aspirations. Threats to our identities in the guise of the irrevocable changes wrought by time, differences with others, and narrative justifications of a state's founding violence motivate this refusal. Furthermore, this refusal spurs the "retreat of ipse identity into idem identity" 50 that Ricoeur cautions divests identity of its narrative mark. Clothing one's identity with the prestige of identity's seemingly immutable character sets up an ideological defense against these threats at the price of others' execration. From this critical vantage-point, the lesser abilities or inabilities of members belonging to disadvantaged groups are a function of systemic injustices linked to the refusal of recognition. The loss of confidence in one's abilities and capacities attests to this refusal's symbolic and material force. The harm done to the confidence in one's own capacities consequently redoubles the harm inflicted by the power 
that an individual or a group exercises over another. Intimidation, coercion, and manipulation thus figure among the forms of violence intrinsic to those instrumental strategies that enforce and maintain asymmetrical cultural, economic, social, and political relations.

Power, in contrast, declares itself through the exercise of the capacities inscribed within the human condition. The "ability to speak, to act on the course of things and to influence other protagonists of an action, the ability to gather one's own life into an intelligible and acceptable narrative," 51 and the ability to hold oneself accountable for one's own actions all attest to the different capacities through which we as human beings relate to others and intervene in the multiple domains of human affairs.

Each capacity has its corollary mode of incapacity. Set against the vocabulary of ability that describes the basis of autonomy, the vocabulary of the inability or lesser ability to exercise the power to speak, the power to act in consort with others, and the power to tell one's own life story expresses the fragility of, and fundamental inequalities among, human beings. For Ricoeur, the fundamental inequality stemming from a lack of mastery of the language on which the law's victory over violence rests - kin to the lack of power to form one's own life plans and to live in accordance with them -is therefore "not so much a natural given as a perverse cultural effect, once the inability to speak well results in effectively being expelled from the sphere of discourse." 52

The fragility fostered by inequalities stemming from these lesser abilities or inabilities is the underside of the autonomy that Ricoeur emphasizes is the "prerogative of the subject of rights." 53 Within the context of the philosophical anthropology Ricoeur espouses, our fragility first expresses itself in the vocabulary of the inabilities or lesser abilities that haunt our claim to exercise our powers as autonomous human beings. Ricoeur stresses that it is "first as a speaking subject that our mastery appears to be threatened and always limited." ${ }^{54}$ For this "power is never complete . . . [or] fully transparent to itself." 55 Moreover, every individual's identity is constructed between the poles constituted by the effort to think for oneself and the rule or domination by another. The fragility of this identity thus stands out against the horizon of the effort to think, speak, and act in accordance with our abilities and capacities.

Setting our fragility against the presumption of the kind of autonomy to which our powers attest highlights the paradox Ricoeur subsequently identifies. This fragility, he explains, "would be pathological if we were not always in some way called on to become autonomous, because we are already so in some way." 56 The capacities that the vocabulary of abilities brings to light consequently make the autonomy of singular individuals the condition of a possibility that juridical practice adopts as its task. Like as yet unfulfilled claims, which Ricoeur argues are the spring of action, the freedom to think for oneself, to judge without prejudice, and to act in accordance with one's own convictions and beliefs accompanies this task. Together with the pursuit of justice, the recognition of everyone's right to these freedoms - and of the capacities that support them-enhances the self-esteem that clothes each person's claim to autonomy with its ethical form through promoting the respect for and dignity of all.

\section{Justice and the Struggle for Recognition}

The recognition of this right and of the ability of each person to think, judge, and decide for herself draws the preceding reflections on the fragility of identity into the orbit of the task that 
the practice of justice sets for itself. Earlier, I drew attention to the moral priority that Ricoeur says belongs to history's victims. This moral priority is indicative of the virtue of justice. This virtue consists in the fact that the practice of justice directs itself toward others who like us are also fragile human beings. Through advancing the opportunity for every individual to exercise her or his capacities and abilities, this practice enlarges the sphere of each person's powers.

However, political bodies and social institutions' formal recognition and assignment of the rights associated with these capacities do not guarantee that each individual is free to exercise them. Nussbaum, for example, points out that the Indian Constitution is a "woman-friendly document." 57 Moreover, she notes that its framers "explicitly state that nondiscrimination is compatible with systematic programs of affirmative action aimed at bettering the lot of deprived groups." 58 At the same time, Nussbaum rightly emphasizes that "various liberties of choice have material preconditions, in whose absence choice is merely a simulacrum." 59 Jayamma's economic circumstances made it impossible for her to go school, and Vasanti achieved economic independence thanks only to the SEWA bank. While the Indian Constitution gives all citizens rights that would seem to guarantee equality of freedoms, the absence of effective enforcement of laws against rape and of educational and employment programs and opportunities makes these rights for women impracticable, and even unreal.

By placing the fragility of our identities against the backdrop of abilities delineated by the vocabulary of our capacities, I want to stress how as yet unfulfilled claims relate to justice's practical task. As I already indicated, Ricoeur identifies this task with the fact that we are all capable of thinking, judging, and deciding for ourselves, of telling our own life stories, and of holding ourselves accountable for our actions. As yet unfulfilled claims stemming from demands on the part of marginalized individuals and groups for a just share in social goods-including education, health care, employment opportunity, and economic mobility-attest to these individuals and group's legitimate aspirations. Just as importantly, these as yet unfilled claims are the spring that motivates and mobilizes individuals and groups in their struggles for recognition.

The process of freedom's actualization is therefore inseparable from the task that justice adopts. Ricoeur reminds us that our experiences of evil offer "an important reason to think that a horizon of unfulfilled claim belongs to the most genuine experience of action." 60 For the philosopher, the problem of evil "belongs to the problematic of the actualization of freedom." 61 Our fragility bears witness to this problem. Moreover, "[h]uman (free) choice appears to carry with it an original wound that affects its capacity for determining itself." 62 Despite our efforts to live in accordance with the maxim that "what ought not to be, namely evil, will indeed not exist,"63 suffering, injustices, and material and symbolic deprivations abound.

Linking the problematic of freedom's actualization to that of the one our autonomy sets us as a task thus brings to the fore the connection between the fragility of the self and the struggle for recognition. This struggle is as much a struggle against others' misrecognition as it is a "struggle for recognition of oneself by others." 64 The struggle for recognition, Ricoeur tells us, aims at this mutual situation. The assurance that I have in my powers and capacities, and the confidence with which I speak, act, and hold myself accountable to others, is couched in my epistemic certitude of these powers and capacities. This certitude paves the way for recognizing myself as the one who speaks and acts. At the same time, this assurance and this confidence also rest on the approbation and approval of others, whose recognition I also seek. 
The task that the practice of justice takes upon itself reaches its apogee when, in response to the vulnerabilities of fragile human beings, it upholds the claim of the right to be different. This right, it could be said, is the emblem of the individual's autonomy. Insofar as this right safeguards the rights and dignity of everyone, it extends the abilities and capacities exercised by some to all. This right, however, is also the source of those conflicts that set one individual, and one group, against another. For in asserting this right, different individuals and groups hold out competing and conflicting visions of the good life, and of who belongs together in the world.

The question of the place justice has in struggles for recognition leads in the end to a consideration of the horizon of as yet unfulfilled claims. If "every expectation must be a hope for humanity as a whole," ${ }^{65}$ how does the claim of the right to be different fit with its own ethical and political implications? Like Kant, Ricoeur holds that "humanity is not one species except insofar as it has one history, and, reciprocally, that for there to be such a history, humanity as a whole must be its subject as a collective singular." 66 That the post-Enlightenment idea of a universal history still seems to be tied to the hegemony of one society or one group of nations clearly continues to pose a threat to subaltern communities and groups. And yet, apart from the dream of a reconciled humanity, the demand to be recognized, respected, and accorded a just place in the world succumbs to an endless struggle.

Does the fragility of our identities condemn us to this endless struggle? Or does this fragility-the underside of the capacities and powers that inhere in the human conditionprovide some reason for hope? To be sure, the vulnerabilities that we experience in the face of changes wrought by the work of time, the ways that others have of leading their lives, and the seemingly ever-present threat of being subjected to another's rule all lead to conflict and strife. Conflicts stemming from competing demands and aspirations ignite tensions among individuals and groups. And yet the capacity to intervene in the order of things through initiating a new course of action, which figures among the abilities of the capable human being, is also reason for hope. This capacity draws strength from the "passion for the possible," 67 which is hope's answer to all amor fati. In the wake of the destruction of all "grand" historical narratives, we must admit with Ricoeur that there is "no plot of all plots capable of equaling the idea of one humanity and one history." 68 At the same time, the permanent ethical and political implications of preserving the tension between our present conditions and the horizon of our as yet unfulfilled expectations sets out our practical task. ${ }^{69}$ Perhaps in the end the dream of a reconciled humanity is a limit idea. And yet, there can be no hope for meeting the challenges of as yet unfulfilled demands and claims apart from advancing the capabilities of all human beings.

The states of peace that assure us that struggles for recognition are not in vain are emblems of this hope. By separating the desire to be recognized from the interminable demand to the right to one's own expectations, states of peace offer an alternative to the "bad infinity" of endless conflict. Experiences of "actual recognition in the exchange of gifts"70 are signs that the motivation that shelters the struggle for recognition from a fascination with violence is not illusory. In the face of completing and conflicting expectations and demands, the hope for a common humanity stands out as the condition and horizon of struggles for recognition. States of peace answer to the fragility of vulnerable human beings. In consort with the virtue of justice, they turn the respect and regard we ask for ourselves toward others. 
${ }^{1}$ Paul Ricoeur, Oneself as Another, trans. Kathleen Blamey and David Pellauer (Chicago: The University of Chicago Press, 2004), 320. These phenomena, Ricoeur explains, far exceed the mishaps and adventures that "can always be made meaningful through the strategy of emplotment."

2 Martha C. Nussbaum, Women and Human Development: The Capabilities Approach (New York: Cambridge University Press, 2000), 106.

3 Nussbaum, Women and Human Development, 106.

4 Nussbaum, Women and Human Development, 15.

5 Nussbaum, Women and Human Development, 108.

6 Nussbaum, Women and Human Development, 138.

7 Paul Ricoeur, Memory, History, Forgetting, trans. Kathleen Blamey and David Pellauer (Chicago: The University of Chicago Press, 2004), 89.

8 Ricoeur, Memory, History, Forgetting, 89.

${ }^{9}$ Ricoeur, Memory, History, Forgetting, 89.

10 Ricoeur, Memory, History, Forgetting, 89. Insofar as the duty of memory links our obligation toward others to the idea of justice's federating force, this duty also bind itself to the logic of hope.

${ }^{11}$ Ricoeur, Oneself as Another.

12 Ricoeur, Memory, History, Forgetting, 81.

13 Paul Ricoeur, Reflections on the Just, trans. David Pellauer (Chicago: The University Press of Chicago, 2007), 79.

${ }^{14}$ Ricoeur, Memory, History, Forgetting, 81-82.

15 Ricoeur, Memory, History, Forgetting, 82.

${ }^{16}$ Ricoeur, Memory, History, Forgetting, 82; see Ricoeur, Reflections on the Just, 142.

17 Paul Ricoeur, Lectures on Ideology and Utopia, ed. George H. Taylor (New York: Columbia University Press, 1986), 311. The "ruling symbols of our identity derive not only from our present and our past but also from our expectations for the future. It is a part of our identity that it is open to surprises, to new encounters. What I [Ricoeur] call the identity of a community is also a prospective identity. What we call ourselves is also what we expect and yet what we are not."

18 Stuart Hall, "Cultural Identity and Diaspora," Identity: Community, Culture, Difference, ed. Jonathan Rutherford (London: Lawrence \& Wishart, 1990), 225.

19 Hall, "Cultural Identity and Diaspora," 225-226.

${ }^{20}$ Ricoeur, Memory, History, Forgetting, 83. At this level, Ricoeur adds, "there is as yet no manipulation, hence no abuse of memory" that would disfigure or systemically deform a group or community's identity. 
21 Paul Ricoeur, The Course of Recognition, trans. David Pellauer (Cambridge, Mass.: Harvard University Press, 2005), 137.

22 Ricoeur, The Course of Recognition, 137. According to Ricoeur, the "idea of social capabilities finds its justification in the pairing of collective representations and social practices. On the one hand, the sphere of representations takes on the role of symbolic mediator and in this ways brings to the fore the question of the identity of the social entities in question. On the other hand, the field of social practices restores the change agent, the social protagonist, to the place of honor, as much on the collective as on the individual level."

23 Ricoeur, Memory, History, Forgetting, 81. "The heart of the problem is the mobilization of memory in the service of the quest, the appeal, the demand for identity."

24 Ricoeur, Memory, History, Forgetting, 85.

25 Paul Ricoeur, Time and Narrative vol. 1, trans. Kathleen McLaughlin and David Pellauer (Chicago: University of Chicago Press, 1984), 46. Whereas ethics "teaches how action, through the exercise of virtue, leads to happiness," its mimetic displacement by the poetics of narrative opens the way to exploring the pathos of the human condition. By giving a narrative texture to the drama of acting and suffering beings, the tragic muthos relates the experience of suffering to the constraints that limit and condition our power to act. Action's mimetic transposition to the fictive world of narrative in turn augments the practical field when, through seeing how the actions of the story's protagonists affect others' lives as well as their own, we reevaluate our own convictions, beliefs, and modes of conduct.

${ }^{26}$ Charles Taylor, "The Politics of Recognition," in Multiculturalism, ed. Amy Gutmann (Princeton: Princeton University Press, 1994). According to Taylor, "our identity is partially shaped by recognition or its absence, often by the misrecognition of others" (25).

27 See Edward Hirsch, "The Imaginary Irish Peasant," PM LA 196 (1991), 1119; Gayatri Chakravorty Spivak, "Can the Subaltern Speak?," Marxism and the Interpretation of Culture, ed. Cary Nelson and Lawrence Grossberg (Urbana: University of Illinois Press, 1988). Spivak points out that the British in India rationalized their actions toward their colonialist subjects as the "white man's burden," By outlawing the practice of sati-widow's self-immolation on the pyre of her dead husband-for example, the British promoted their image as a civilizing force. Through redefining widows' selfimmolation as a crime, the British discourse on sati made women the "object of protection from her own kind" (299). This British narrative of saving "brown women from brown men" (296) promoted the authority of British rule through setting the British definition of sati against its native representation. See Stoler, "Imperial Debris: Reflections on Ruins and Ruination." Stoler similarly points out that "[c]olonialism has been predicated on guarding natural and cultural patrimonies for populations assumed to be needy of guidance in order to value and preserve them" (198).

28 See Ricoeur, The Course of Recognition. Ricoeur stresses that the "seriousness of the lack of recognition of which members of these groups feel themselves to be the victims comes from the internalizing of this image in the form of self-deprecation" (213-214). Essentialist representations that exoticize or denigrate others - the negative underside of the vacuous prestige of one's own claim to an 
immutable identity-shore up the ideological justification of the victor's hegemonic rule. These representations therefore have a two-fold objective. Not only do they serve to justify the use of power that one group exercises over another, but they also aim at disarming a subjugated population by depriving it of the capacities and symbolic resources through which it might offer any resistance. Once internalized, self-deprecating images inflame resentments against a ruling authority's refusal to recognize its victims. Convictions regarding one's own inabilities thus fuel the belief in one's own need to depend upon those whose cultural, social and political authority is the source and cause of suffering and deprivation.

29 Ricoeur, The Course of Recognition, 213-14.

30 Nussbaum, Women and Human Development, 116.

31 Nussbaum, Women and Human Development, 117.

32 Nussbaum, Women and Human Development, 117.

33 Ann Laura Stoler, "Imperial Debris: Reflections on Ruins and Ruination," Cultural Anthropology 23: 2 (2008), 194.

34 Stoler, "Imperial Debris," 208.

35 Paul Ricoeur, Reflections on the Just, trans. David Pellauer (Chicago : The University Press of Chicago, 2007), 85.

36 See Paul Ricoeur, Hermeneutics, trans. David Pellauer (Cambridge: Polity Press, 2013). For Ricoeur, the principle of morality not only accents the conflictual side of interaction, but it also highlights the essential asymmetry between action and undergoing what someone else does. "In this sense, the principle of morality does not set side-by-side, or face-to-face, two agents, but an agent and a patient of some action. A patient ... . [is] someone to whom something is done" (37).

37 Ricoeur, Oneself as Another, 320.

38 Ricoeur, Oneself as Another, 320.

39 Ricoeur, Oneself as Another, 318.

40 Ricoeur, Oneself as Another, 321.

${ }^{41}$ Ricoeur, Oneself as Another, 324.

42 Ricoeur, Oneself as Another, 330.

43 Ricoeur, Oneself as Another, 330; see Ricoeur, Memory, History, Forgetting, 89.

44 Ricoeur, Oneself as Another, 351.

45 Ricoeur, Oneself as Another, 351.

${ }^{46}$ Ricoeur, Oneself as Another, 330.

47 Ricoeur, Oneself as Another, 330; see Ricoeur, Hermeneutics. In formulating the principle of morality, Ricoeur adopts as his guideline the Golden Rule as "formulated by Hillel, Saint Paul's Jewish teacher: 'Do not do to your neighbor what you would not like him to do to you.'" (36-37). 
${ }^{48}$ Ricoeur, Oneself as Another, 318. Original emphasis.

49 Ricoeur, Oneself as Another, 25.

50 Ricoeur, Memory, History, Forgetting, 81.

51 Ricoeur, Reflections on the Just, 75.

52 Ricoeur, Reflections on the Just, 76; see Spivak, "Can the Subaltern Speak?"

53 Ricoeur, Reflections on the Just, 73.

54 Ricoeur, Reflections on the Just, 73.

55 Ricoeur, Reflections on the Just, 73.

56 Ricoeur, Reflections on the Just, 73.

57 Nussbaum, Women and Human Development, 24.

58 Nussbaum, Women and Human Development, 25. The "principle of affirmative action, for both gender and class, is written into the Constitution itself."

59 Nussbaum, Women and Human Development, 53.

60 Paul Ricoeur, Figuring the Sacred: Religion, Narrative, and Imagination, trans. David Pellauer (Minneapolis: Fortress Press, 1995), 211. The breach that "prevents our partial experience of fulfilled achievements from being equated with the whole field of human action" (211) attests to the evil of violence, which afflicts action at its root. See Ricoeur, Oneself as Another. For Ricoeur, "the enigma of the origin of evil is reflected in the enigma that affects that actual exercise of freedom" (218).

${ }^{61}$ Ricoeur, Figuring the Sacred, 215.

62 Ricoeur, Oneself as Another, 218. The "enigma of evil is reflected in the enigma that affects the actual exercise of freedom. The fact that this penchant is always already present in every opportunity to choose but that it is at the same time a maxim of (free) choice is no less inscrutable than the origin of evil."

63 Ricoeur, Oneself as Another, 218.

64 Ricoeur, The Course of Recognition, 258.

65 Paul Ricoeur, Time and Narrative vol. 3, trans. Kathleen McLaughlin and David Pellauer (Chicago: University of Chicago Press, 1988), 214.

${ }^{66}$ Ricoeur, Time and Narrative vol. 3, 214.

67 Ricoeur, Figuring the Sacred, 206.

68 Ricoeur, Time and Narrative vol. 3, 259.

69 Paul Ricoeur, From Text to Action, trans. Kathleen Blamey and John B. Thompson (Evanston: Northwestern University Press, 1991. Ricoeur explains that the "tie between historical action and a 
past that is received and not made . . . preserves the dialectical relation between the horizon of expectation and the space of experience" (220). The necessity of maintaining this tie defines the task that confronts us: to prevent the tension between the space of our experiences and the horizon of our expectations from becoming a schismatic rupture. The tendency in the modern age for this space of experiences to contract has as its counterpart the tendency of this horizon to recede more quickly than it can be approached. See Ricoeur, Time and Narrative vol. 3. But then, Ricoeur says, the "present is wholly a crisis when expectations take refuge in utopia and when tradition becomes only a dead deposit of the past" (235). On the one hand therefore, we "must resist the seduction of purely utopian expectations, [which] . . . lacking an anchorage in experience" (215), can only make us despair of any practical responses to the problems and challenges confronting us. On the other hand, "we must also resist any narrowing of the space of experience" (216.) and the tendency to regard the past as unchangeable. The force of the present proceeds from the interminable transactions between the way we bring utopian expectations into contact with the present and the way that we reactivate the past's latent potentialities.

70 Ricoeur, The Course of Recognition, 246. 